\title{
Interaction of banks and development institutions in the system of innovation priorities
}

\author{
Elena Altukhova ${ }^{1}$, Veronika Nikeryasova $^{1}$, and Yana Ivanova $^{1}$ \\ ${ }^{1}$ Plekhanov Russian University of Economics, Department of financial management, 117997, Moscow, Russia
}

\begin{abstract}
The age of new technologies forms a new paradigm for the functioning of the economic system. New living conditions require serious and consistent changes in all areas. The current dynamics of development determines the emergence of new structures and mechanisms of interaction. The driving force behind the implementation of breakthrough technologies is development institutions that facilitate the implementation of new projects. The essential moment in the implementation of new requirements is the priorities of digital development. In this regard, the latest legislative innovations, as well as a number of measures for the restructuring of development institutions have given a new impetus to ensure progressive innovative development. The article discusses new conditions for the development of institutions, and also offers promising areas of interaction between banks and development institutions. The analysis of the models of work of development institutions is carried out. The main forms of financing innovative activities are considered. The mechanisms of interaction of the participants in the process have been determined, including taking into account regional characteristics. Legislative initiatives aimed at stimulating the development of innovations have been analyzed. The formulated proposals will be able to ensure a more dynamic development of innovations, which will allow launching the entire chain of updates in the technological field.
\end{abstract}

\section{Introduction}

The founder of the theory of economics based on innovation is J. Schumpeter, who at the beginning of the twentieth century began to talk about "new combinations" on which, in his opinion, economic growth is based. The question of whether innovations are based on new technological opportunities, scientific knowledge, social needs, or whether they are determined by market requirements remains unresolved.

Modern trends in the development of science and technology require new approaches not only in the methodological, but also in the infrastructure aspect. The need for a technological breakthrough is felt by any modern economy.

Today, the active interaction between business and the scientific community is becoming particularly important, allowing for the implementation of major technical projects. Technological valleys are an example of such interaction in accordance with the requirements of the legislation.

Many legislative initiatives have been adopted in this direction today. For example, in 2017, the law on Innovative Scientific and Technological Centers (INTC) was adopted. As part of the implementation of this legislative initiative, a decree on subsidizing projects related to the creation of "technological valleys" was signed in September 2020. This tool is designed to assist technology companies and startups, as well as to organize the transfer of the results of intellectual activity of universities into commercial circulation, while involving students and researchers in the development of technologies in demand on the market. So in the Tula region there will be an innovative scientific and technological center (INTC) "Composite Valley". In the near future, it is planned to create a network of such centers that will become part of a single innovation ecosystem, which will ensure the development of technologies based on the consistency of the requirements of the economic system and the capabilities of the scientific community.

In parallel, in accordance with Federal Law No. 473 of 29.12.2014 "On Territories of advanced Socioeconomic development in the Russian Federation", the formation and development of single-industry towns has been implemented since 2015, in terms of allocating territories within the country with the necessary infrastructure and benefits for starting production. Territories of advanced development (TAD) are economic zones with preferential taxation, simplified administrative procedures and other privileges created for the development of investment activities, accelerated economic development and improving the lives of the population.

As of 31.03.2020, the results of the work of the TAD in single-industry towns formed the following list of indicators:

- 639 residents; 
- more than 27 thousand jobs were created;

- attracted more than 69 billion rubles of investment;

- the revenue of residents amounted to more than 149 billion rubles.

Considering the Rating of innovative development of the subjects of the Russian Federation, it should be noted that the regions that demonstrate maximum readiness for the future are evenly distributed across the country and are present in seven of the eight federal districts: Central (4 regions), Volga (4), Ural (3), Siberian, NorthWestern, Southern and Far Eastern, which indicates sufficient innovation potential.

One of the most significant normative acts, which is based on the implementation of most of the changes in the field of progressive economic development, is Presidential Decree No. 204 of May 7, 2018 "On national goals and strategic objectives of the development of the Russian Federation for the period up to 2024". In accordance with the Presidential Decree, national projects were formed in twelve main areas. More than half of the total budget funds generated for the implementation of these projects are focused on two areas that are basic for the implementation of innovations: "Human capital" and "Economic Growth".

Thus, today, the basic legislative initiatives have been formulated to launch serious innovative processes, the result of which will be significant technological changes.

At the same time, the issue of infrastructure changes remains not fully worked out, the need for which becomes more and more urgent with the approach of the deadlines for the implementation of the indicators of the roadmap of national projects. In this regard, the systemic nature of the reform and ensuring the coherence of the economic interests of the participants in the process, taking into account the synchronization of the activities of infrastructure elements.

\section{Methods}

One of the key links that ensure the effectiveness of innovation processes is the well-coordinated work of development institutions.

Development institutions perform several functions:

- social (directing funding to sectors and regions that are important for national development);

- financial (filling in the gaps of the financial market and providing demand for various financial instruments by searching for and structuring projects), stabilizing (playing a countercyclical role);

- regulatory (creating and maintaining high standards, including social and environmental ones). The main objective of the financing mechanism through development institutions is to distribute risks between the state and business, and to use market incentives for the effective implementation of the project. Thus, the state assumes political, administrative, and innovation risks, while private businesses assume investment and marketing risks.

The main principles of financing through development institutions include:
- the principle of co-financing;

- targeted nature of funding;

- non-monetary support;

- attracting foreign investors;

- mechanism for exiting the project.

Until recently, the basic development institutions in Russia were " VEB.RF", JSC" Rusnano", JSC "Russian Venture Company", the Development Fund of the Center for the Development and Commercialization of New Technologies (Skolkovo). The listed structures implemented their functions in the form of:

1) financing of business projects;

2) providing infrastructure support;

3) participation in R \& D financing.

The development institutes also included the Agency for Strategic Initiatives, the Innovation and Investment Market (RII of the Moscow Exchange), the Federal State Autonomous Institution "Russian Fund for Technological Development", and the Fund for Promoting the Development of Small Forms of Enterprises in the Scientific and Technical Sphere.

As part of the implementation of the national development goals for the next 10 years, the Government of the Russian Federation in November 2020 significantly changed the composition and structure of development institutions. As a result, more than four dozen development institutions were reformed.

In accordance with the Decree of the Government of the Russian Federation of 31.12.2020 No. 3710-r approved:

- List of development institutions to be liquidated;

- list of development institutions to be modernized;

- action plan ("road map") for the transfer of development institutions under the management of the state Development Corporation " VEB.RF".

As a result, a list of federal institutes of innovative development was formed, which included 11 organizations.

At the end of December, key performance indicators (KPIs) for state corporations and development institutions were approved. KPIs will be divided into two groups:

- financial indicators that characterize the profitability of the organization;

- industry-specific issues related to national development goals.

The first group includes the coefficients of return on invested or equity capital, the dynamics of revenue, and the income of shareholders. The second category includes the number of jobs created, the volume of investments attracted, budget efficiency, and the contribution to non-primary non-energy exports.

The key instruments for implementing state policy in this area are development institutions, which can act as a catalyst for private investment in knowledge-intensive sectors of the economy. Thus, it is assumed that the development institutions will perform the functions of operators in the implementation of high-tech projects.

It should be borne in mind that any development should take into account examples of best practices. In terms of stimulating innovation activity through the venture financing system, we can consider the 
mechanism of the Israeli Venture Investment Fund Yosma.

The catalyst for the venture capital industry in Israel was the state-owned investment company Yosma (the" initiative"), which acted as a "fund of funds". Yosma's capital was invested in ten newly created private equity funds with a capital of $\$ 20$ million.

The success factors of the project were the following aspects:

- using international experience: the formed funds were required to have an American or European partner, so that they would teach their Israeli colleagues the methods and principles of investing, developing companies and conducting the fund's business;

- the principle of co-financing: in each case, the stake owned by the government was no more than $40 \%$, which left control of the funds in private hands;

- using the potential of the education sector: universities were invited to participate in the program;

- creating incentives to increase capitalization: from the very beginning, the government announced its intention to privatize the assets it acquired during the implementation of the program, for this purpose, funds created with the participation of Yosma were offered options to buy back shares owned by the state at a fixed price plus a limited percentage (5-7\% per annum).

The model of the German development bank KfW is often cited as an example of financing a development institute. All KfW loans that are concessional are subsidized by the state according to the following scheme: the bank borrows part of the funds for issuing the loan on market terms, and the concessional element is financed from budget funds. Innovative projects and startups enjoy preferential financing. In the field of energy efficiency, for example, this is technically done as follows:

- at the first stage, the bank provides a loan from its own funds on market terms;

- at the second stage, when the declared indicators in the field of energy efficiency are achieved, the funds are returned to the borrower from the budget or part of the debt is written off.

An example of another financing model is the Industrial Bank of Kuwait, whose loan portfolio is divided into two parts. One part of the portfolio is financed by the state fund at a preferential rate of 3.5\%. The other part of the portfolio is formed by loans from foreign banks, which make up $10 \%$ of the bank's liabilities.

Another example of a sustainable model for financing development institutions is the work of the Provincial Bank in Turkey, where $80 \%$ of its liabilities are generated by monthly deductions of $2 \%$ of the total tax revenues of the provinces and municipalities.

Another example is the work of the Bank of North Dakota. All funds of the state budget funds are kept on deposit in this bank. The bank has the ability to issue cheaper and longer loans. Concessional deposits account for $77 \%$ of the bank's liabilities, and another $18 \%$ are concessional loans received from the Federal Mortgage Lending Bank.
Thus, we can conclude that it is the banks that, due to the peculiarities of their work, act as development institutions. This aspect makes us think about the need for close centralized interaction of development institutions with the banking sector.

\section{Results}

Taking into account the Russian practice of financing innovative projects, it should be noted that in form it is divided into project and venture (Fig. 1). If we talk about startups, then the main source of funding is the authorized capital. Debt sources are formed mainly from debt, equity and mixed financing.

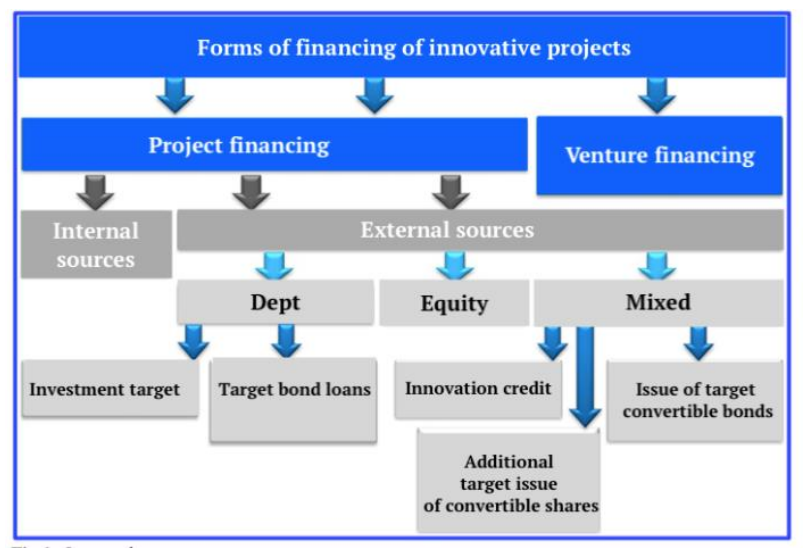

Fig. 1. Forms of financing of innovative projects.

Typical external sources of financing include:

1) Investment credit and credit lines.

2) Targeted bond loans.

3) Equity project financing in the form of an additional issue of shares or the establishment of a separate entity for an innovative project.

4) Innovation credit.

5) Additional issue of convertible shares.

6) Issue of convertible bonds.

An intermediate position between internal and external sources is occupied by shared project financing, which is carried out in the form of:

1) Formation by the parent company or its participants together with the attracted investors of a new innovative company with the formation of the authorized capital that will meet the development and commercial implementation of innovations.

2) Additional issue of shares for the purpose of financing a separate project within the existing company.

The first option is more suitable for Russian conditions, as it allows investors to keep their capital under control and prevent its misuse. This is especially important in the context of the riskiness of innovative projects.

A significant justification for the deployment of work in this direction is the Government Order No. 3710-r of 31.12.2020 on the transfer of development institutions under the management of the State Development Corporation "VEB.RF".

According to experts, the legal form that defines the mechanisms of management and control is important for 
the activities of development institutions. Development institutions created in the form of joint-stock companies with state participation are more independent in decision-making compared to budget institutions. Based on the experience of the last fifteen years, it can be noted that the most effective development institutions are those that use grant (at the early stages) and credit (at all stages) support for business.

Synchronization of interaction between development institutions and commercial banks should ensure a holistic interaction of the system, which makes it possible to coordinate the interests of all its participants.

It is possible to subsidize bank loans by development institutions.

By interacting with development institutions, banks will be able to place temporarily available funds on the one hand, and on the other - to provide resources to economic entities that need it, while performing the main function - the redistribution of capital.

The need for banks and development institutions to participate in the implementation of national projects is steadily increasing. Half of the projects are directly related to the participation of the banking sector in the implementation procedure.

For example, the national project "Digital Economy of the Russian Federation" needs to form a complete system of project financing. The development of digital technologies is possible on the basis of the use of venture financing.

Given the high risk, venture capital financing is not among the main banking operations. Because it does not comply with the basic principles of the banking sector. At the same time, credit institutions can finance this process through interaction with development institutions, which will be able to take on the risks of non-fulfillment of the project, compensating the client for the reduction in the interest rate.

The implementation of the national project "Small and medium-sized enterprises and support for individual entrepreneurial initiatives" can be organized on the basis of ensuring access to concessional financing. As support measures, an annual increase in concessional loans to small and medium-sized businesses, including individual entrepreneurs, can be included. This initiative is already being observed as part of the implementation of the monetary policy of the Bank of Russia in terms of reducing the key rate. Also, the Bank of Russia may apply a system of preferential lending and profit taxation to credit institutions servicing these loans.

In order to create an additional impetus for the development of the innovation sector, as well as taking into account the low creditworthiness of small and medium-sized businesses, this area requires more detailed study in terms of legislative initiatives related to the activation of banks ' participation in this process. Development institutions can act as a guarantor of the implementation of the above measures. It is also necessary to develop special credit products aimed at supporting the development of SMEs. Microfinance organizations that have sufficient experience in interacting with this segment can also be involved in this process.
It is also important that each participant in the process has a certain set of preferences that ensure consistent interaction.

In particular, the legislator should clearly establish a list of national projects in which commercial banks can participate, while having a number of advantages. As part of the search for additional sources of long-term money to finance large-scale projects, the Bank of Russia considers the need to develop securitization as an issue of securities backed by any assets. Based on the specifics of the transaction (currently, the risk coefficients vary in the range from $100 \%$ to $1250 \%$ ), it is proposed to use a preferential risk assessment for securitization based on the possibility of reducing the risk coefficients to $10 \%-15 \%$.

The resources raised during the issue of securities can be used to finance long-term projects, including small and medium-sized businesses. It is proposed to set the minimum amount of formed reserves for such loans at the level of $10 \%$. At the same time, this condition should not apply to loans allocated for the purposes of federal targeted programs or for investments in strategic projects of the military-industrial complex. The reduction in lending to mergers and acquisitions, according to the Bank of Russia, will allow the formation of resources for their use in the system of long-term project financing.

An example of synchronizing the work of development institutions is the activity of the National Development Institute of VEB.RF, which participates in the management of development institutions and the formation of an algorithm for joint work on projects, which will ensure the effective use of financial and nonfinancial support tools, including state aid.

According to the leading foreign and Russian rating agencies, the credit rating outlook of the State Development Corporation of Russia is characterized as stable.

Implementing its financial policy of VEB.RF participates in the development of priority sectors of the economy, as well as in major national projects aimed at sustainable economic development.

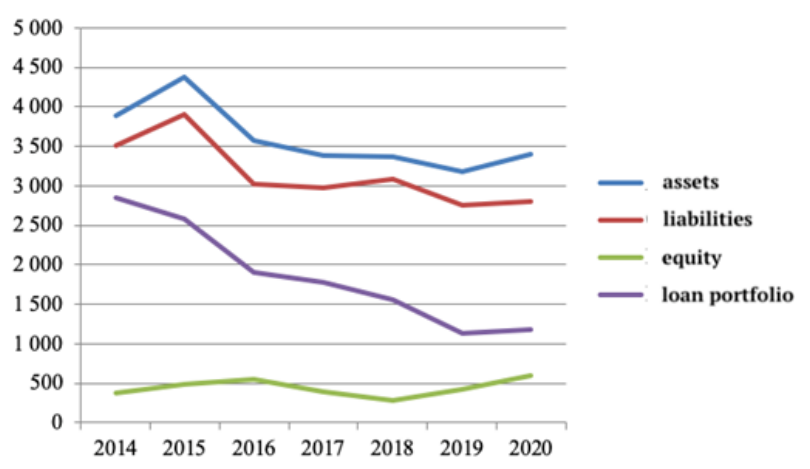

Fig. 2. Dynamics of VEB.RF's main performance indicators for the period from 2014 to 2020, billion rubles.

As can be seen in Figure 2 for the period from 2015 to 2019, VEB's loan portfolio more than doubled. This reflects the real state of the current economic situation and requires special measures to maintain investment 
activity not only on the part of the legislative field, but also in terms of systemic changes.

Today, VEB.RF implements the financing of investment projects under the "project finance factory" mechanism in accordance with the procedure and conditions established by the "Project Finance Factory" program. Within the framework of this program, VEB.RF provides loans to LLC "Specialized Project Finance Company Project Finance Factory", established by Vnesheconombank in accordance with the legislation of the Russian Federation, 100 percent of the share in the authorized capital of which belongs to Vnesheconombank, and provides it with financial support in other forms.

As part of the implementation of the VEB.RF project financing factory checks the idea for compliance with the criteria of the Factory and decides on the possibility of including the project in the Factory and carries out the structuring of financing taking into account state support by concluding a syndicated loan agreement. VEB.RF is engaged in obtaining subsidies and state guarantees, issues bonds, provides creditors with access to information resources with data on the implementation of the project, acting as a project manager.

Another example of interaction between banks and development institutions is the activity of a large specialized state bank, JSC "SME Bank". The key activity of the bank within the framework of state financial support programs was lending to small and medium-sized businesses, provided through partners and directly.

The business lending schemes of JSC "SME Bank" were implemented as follows:

1) through partner organizations that help implement financing on the terms of the SME bank. Such organizations include both large banks and microfinance organizations.

2) the bank itself issues loans, where priority is given to customers in the production and innovation sectors. The credit facilities do not include: gambling, insurance companies, non-state pension funds, etc.

The basic sources of forming the resource base of the SME Bank include interbank funds, as well as loans from VEB.RF and the Bank of Russia. In 2007, 100\% of the bank's shares were included in the authorized capital of VEB.RF. Since 2016, 100\% of the shares of SME Bank belong to the joint-stock company "Federal Corporation for the Development of Small and Mediumsized Enterprises" (SME Corporation).

It is important to develop cooperation between regional banks and development institutions on the example of VEB.RF's activities and SME banks with the participation of private investors and syndicates of banks.

Given the federal structure of the Russian Federation, each subject should have its own financial independence, which is possible in an effectively functioning banking system. At the same time, it is important to take into account the specific features of the organization of the economic structure of the region due to the natural and climatic, geographical, infrastructural and other aspects that affect its economic development.
It is particularly important to establish branches or representative offices of large banks at the local level, which will deal with development programs in accordance with regional needs.

In this regard, it is necessary to pay attention to the development of regional banks that will implement certain development projects taking into account the needs of the region. This aspect is important to take into account when developing a system of interaction with development institutions, which, within the framework of their regional offices, will be able to evaluate the project and structure funding taking into account regional characteristics. It is also possible to consider the possibility of forming state-owned banks at the regional level with the directions and features of the organization of work through partner organizations and directly, when the bank itself issues loans, giving priority to customers in the production and innovation sectors.

In addition, it is important to pay attention to the need to change the methodology for evaluating individual projects, taking into account regional specifics, with a corresponding change in the criteria values of a number of evaluation indicators.

It is necessary to change the regulatory values of a number of risk indicators and reserve requirements for banks involved in the implementation of regional projects. It is also worth supporting development institutions focused on regional development. In order to better facilitate the implementation of new projects, it can be proposed to halve the indicators of reserve requirements for banks, as well as to change the regulatory requirements in terms of the maximum amount of risk per borrower or a group of related borrowers, as well as the maximum amount of large credit risks

It is important to change the requirements for projects participating in the competitive selection regarding the minimum amount of funds required for the implementation of the project and the implementation deadlines themselves. You can also add additional conditions that are specific to the region's economy.

\section{Discussions}

In general, the successful implementation of innovative development on the territory of the Russian Federation is possible taking into account a number of essential points that require systematic approaches.

Summarizing the above, the system for stimulating the implementation of innovation priorities can be presented in the following form (Table 1). 
Table 1. Innovation incentive system.

\begin{tabular}{|l|l|l|}
\hline \multicolumn{1}{|c|}{ Event } & \multicolumn{1}{c|}{$\begin{array}{c}\text { Implementation } \\
\text { tool }\end{array}$} & $\begin{array}{c}\text { Implementation } \\
\text { system }\end{array}$ \\
\hline $\begin{array}{l}\text { Improving the } \\
\text { feasibility of } \\
\text { national projects }\end{array}$ & $\begin{array}{l}\text { Project financing } \\
\text { factories for each } \\
\text { region }\end{array}$ & $\begin{array}{l}\text { Effective regional } \\
\text { development } \\
\text { program }\end{array}$ \\
\hline $\begin{array}{l}\text { Ease of working } \\
\text { with development } \\
\text { institutions for } \\
\text { business }\end{array}$ & $\begin{array}{l}\text { A single platform } \\
\text { for all participants } \\
\text { of the process }\end{array}$ & $\begin{array}{l}\text { A distributed } \\
\text { database with } \\
\text { different levels of } \\
\text { access to } \\
\text { information }\end{array}$ \\
\hline $\begin{array}{l}\text { synchronization } \\
\text { of the functioning } \\
\text { of banks and } \\
\text { development } \\
\text { institutions }\end{array}$ & VEB.RF activities & $\begin{array}{l}\text { consolidating of } \\
\text { the work of } \\
\text { development } \\
\text { institutions within } \\
\text { the framework of } \\
\text { national } \\
\text { development goals }\end{array}$ \\
\hline $\begin{array}{l}\text { attracting private } \\
\text { investors to co- } \\
\text { finance innovative } \\
\text { projects }\end{array}$ & $\begin{array}{l}\text { tools to encourage } \\
\text { private investors ' } \\
\text { participation }\end{array}$ & $\begin{array}{l}\text { review of funding } \\
\text { sources for } \\
\text { development } \\
\text { institutions }\end{array}$ \\
\hline
\end{tabular}

It is possible to achieve high performance in the implementation of national projects, based on the formation of a project financing factory for each region that has an effective development program.

The convenience of using the assistance provided by development institutions is important for business. To do this, it is necessary to form a single platform, where the unity of services provided by institutions will be presented in an accessible form for business, indicating the mechanism for implementing a particular procedure. Perhaps in the near future, such a platform is possible on the basis of VEB.RF

Such a system should accumulate information about all support measures, taking into account the areas of activity of a particular company. Such a distributed database with different levels of access to information should allow process participants (development institutions) to provide access to the process.

It is especially important that all development institutions interact in a single algorithm and uniformly perform a particular operation. It is necessary to observe the unity of the document flow and a single digital environment available to the client in the online service.

At the level of implementation of regional development programs, a similar platform should work.

In terms of regulatory regulation, the mechanism of interaction between banks and development institutions can be formed by analogy with the work of the DoddFrank Law, which works within the framework of a single platform for interaction between the Financial Stability Oversight Council and the Financial Research Office. Such a system of interaction provides guarantees for the protection of investors ' rights and increases the level of financial stability, which is especially important in the system of organizing effective interaction between development institutions, the banking sector and private investors.

The key issue in developing the main directions for synchronizing the functioning of banks and development institutions is the consolidation of the work of development institutions within the framework of national development goals in the system of national projects. VEB. RF should become the coordinator for evaluating future projects and organizing their financing.

At the same time, it is important to take into account the investment strategy, the systematic nature of the ongoing reforms, the sufficient motivation of the participants in the process, as well as the clearly formulated role of development institutions in supporting economic transformations in terms of the development of certain areas of economic activity, taking into account technological features. The innovation component requires particularly careful study, taking into account the serious risks and the degree of priority of the development of certain areas. Since almost all investment projects of development institutions are carried out in the system of public-private partnership, it is important to take into account the interests of private investors and partners of development institutions. At the same time, development institutions should encourage the development of innovations, which should be clearly reflected not only in their mission and development strategy, but also in the structure of financing of some funding sources.

\section{References}

1. Memorandum on the financial policy [Electronic resource], Order of the Government of the Russian Federation, WEB.RF, 1510-r (23 July 2018) Available at: https:/web.rf/files/?File=ff666364784d3143c3e5 1969e2e7d52d.pdf

2. On approval of requirements for the form and content of reports on the implementation of programs of activities of state corporations (companies), public companies, as well as requirements for the form and content of reports on the achievement of key performance indicators of public corporations (companies), public companies [Electronic resource], Decree of the Government of the Russian Federation, 2447 (31 December 2020) Available at: http:/government.ru/news/41285/

3. The order of the Government of the Russian Federation [Electronic resource], 3710-r (31 December 2020) Available at: http://static.government.ru/media/files/pPBOA9S Sd3DTrRN2BASly7PFcUcAcIof.pdf

4. A.A. Vershinina, L.V. Goryainova, O.A. Zhdanova, T.P. Maksimova, State of the Investment Fund Market of as an Indicator of the Country's Socio-Economic Development, Journal of Internet Banking and Commerce, Special Issue: Finance, Services Sector and Commerce: Innovations and Investments, SCOРUS, РИНЦ, 21 (S3) (2016)

5. A.A. Vershinina, O.A. Zhdanova, T.P. Maksimova, D.G. Perepelitsa, International Journal of Economics and Financial Issues, The formation of indicator framework for effective 
assessment of investment attractiveness of the region, 5 (3S), 136-141 (2015)

6. E. Altukhova, Synchronization of the work of Russian banks and development institutions in the system of implementing national projects, Bulletin of the PRUE G.V. Plekhanov, 1, 29-36 (2021)

7. A. Ivanter, A. Mechanic, E. Obukhova, N. Ulyanov, Reform of the system of negative KPI [Electronic resource], Expert 49 (2020) Available at: https://expert.ru/expert/2020/49/reformasistemi-otritsatelnogo-kpi/

8. I. Hasanov, The international experience of creation and functioning of institutes of development [Electronic resource], Transport business in Russia Available at: https://cyberleninka.ru/article/n/mezhdunarodnyy -opyt-sozdaniya-i-funktsionirovaniya-institutovrazvitiya/viewer

9. A.K. Morozkina, National development institutions and budgetary risks: international and Russian practice, Issues of state and municipal management, 3, 175-192 (2019)

10. O. Mukhametov, The Central Bank wants to make money longer The regulator outlined measures to stimulate long-term investments [Electronic resource], Kommersant newspaper, 112, 2 (29.06.2018) Available at: https://www.kommersant.ru/doc/3670888

11. G. Akerlof, M. Spence, J. Stiglitz, Problemes Econ. P. l'asymetrie au coeur de la nouvelle microeconomie, 2734, 1924 (2001)

12. J. McMillan, The End of Banking: Money (Credit, and the Digital Revolution Corpus, 2019, 256)

13. Omar Costa, Jawad Khan, Alfonso Natale, Rethinking bank risk in emerging markets (USA: McKinsey \& Company, September 2014)

14. D.I. Stepanova, S.S. Hasanova, L.M. Allanina, B.I. Skorodumov, A.V. Novikov, Digital technologies in the global economy: Technologies and innovations International Journal of Innovative Technology and Exploring Engineering, 8 (8), 2775 (2019)

15. S.Weiss, Lecture notes 10-12 it's about credit rationing (1981)

16. Commodity futures trading commission [Electronic resource] Available at: https://www.cftc.gov/LawRegulation/DoddFrank Act/index.htm 